\title{
Development of risk-based standardized WBS (Work Breakdown Structure) for quality planning of high rise building architectural works
}

\author{
Mirradewi Rianty ${ }^{1,}$, Yusuf Latief $^{1}$, and Leni Sagita Riantini $^{1}$ \\ ${ }^{1}$ Project Management Program, Departement of Civil Engineering, Universitas Indonesia, Depok \\ 16424, Indonesia
}

\begin{abstract}
Work Breakdown Structure (WBS) is a breakdown of project work into smaller components so it can be better managed. Although each project is unique, most buildings can be standardized in their activities to enable the provision of a stronger forecast for project management. Quality performance is also important to be controlled and risk consideration approach is now required for overall quality management process in the updated ISO 9001. Therefore, the development of risk-based WBS for quality planning is proposed. The objective of the study was to develop risk-based WBS for high-quality building architectural works. The research consisted of several stages with qualitative risk analysis method. The result indicates that standardized WBS consists of 5 primary levels and 2 complementary levels, with 14 dominant risk variables on quality performance, and recommended risk responses as the development.
\end{abstract}

\section{Introduction}

Rework intensity on architectural works is found to be the most often in construction industry [1], there are many cases on high-rise apartment building in Jakarta, Indonesia indicate bad quality of building leaks and cracks [2]. Bad quality performance relates with the poor reliability of the planning process, where the contractors are unable to manage the increasing complexity of the projects [3]. In the latest developments of international standard of quality management ISO 9001, the approaches of risk considerations are required for the whole process to improve results through proactive precautions [4].

The development of Work Breakdown Structure (WBS) is the first step in the planning process after defining project requirements. The definition of activity is the most critical in planning process, that a project manager should spend more effort to identify the project activity using the WBS [5]. WBS is a breakdown of project works into smaller components so it can be better managed and measured against the ultimate completion [6]. Although each project is unique, most building construction works can be standardized to enable the provision of basic activities to have robust estimates for project management [7]. Therefore,

*Corresponding author: mirradewi.rianty@gmail.com 
the development of risk-based standardized WBS of high rise building architectural works for quality plan is proposed. The objectives of this research are to identify standardized WBS for high-rise building construction (case study of apartment building's architectural works), to identify risks from the standardized WBS that may cause quality incompliances, and to develop risk-based standardized WBS for architectural works

The scope of the study is limited to the following: (1) It is directed to practitioners of the construction project, (2) The research conducted on high-rise construction project in the last 5 years at Jabodetabek area Indonesia, and (3) The performance of the project referred in this study is the achievement of the quality performance of the construction work

\section{Risk based-standardized WBS for quality planning}

The approach followed by the project team to develop WBS revolves around the application of previous WBS with some changes, progressive breakdown of the work required for the project, and the development of WBS-based deliverables with focus on the basic function of final product [8]. Instead of developing WBS for each project, it is sometimes appropriate to develop a general WBS for typical project, then the necessary segment can be modified. It is suitable for organizations which perform similar projects [9]. Construction activities are highly predictable and there are consistent rules that governs the selection of activities, so it is feasible to develop standard activity [10].

A quality plan must determine all procedure and measurement (tests, inspections, etc.) to assess progress towards goal requirements [11]. WBS can be used as a planning approach to improve project performance, the practice was reported to reduce rework on quality performance - mostly associated with reduced change of scope on work, and increased control on site for industrial construction projects [3]. The WBS standardization framework is also recommended to support integrated planning and supervision [12].

WBS-based planning with risk considerations was also developed for software projects, which were found to increase modification flexibility so as to reduce risk of change in planning [13]. The WBS-based risk identification on real estate projects also indicates that each stage of the task is more intuitive, the risks are easier to identified and controlled [14].

\section{Research methodology}

The methodology in this research was based on the following: (1) To identify the standardized WBS, the data are collected from analysis of archives, benchmarks, and interview of experts with Delphi method; (2) The risk identification derived from the standardized WBS category and the variables are obtained from literature analysis, then questionnaire are distributed to respondents from construction background. From returned questionnaires, a qualitative risk analysis is conducted using PMBOK risk matrix to seek dominant risk variables; (3) To develop risk-based standardized WBS, the highest ranked risk variables are analysed for their preventive and corrective actions through pattern recognition, and also through RBSxWBS matrix, the mapping of risk variables (Risk Breakdown Structure) which has impact on WBS item. RBSxWBS matrix is using dominant risk variables for the RBS input, and Pareto method as an approach to select certain dominant architectural work for the WBS input. Result of the risk responses is used to develop the standardized WBS. There are 6 experts interviewed using questionnaire. 


\section{Findings}

\subsection{Standardized WBS}

The result of standardized WBS consists of 5 primary levels and 2 complementary levels. The primary levels are:

- WBS Level 1 Project Name: The highest level and representation of the entire project.

- WBS Level 2 Work Section: The decomposition of the construction elements of the project which as a whole is the entire high-rise building project.

- WBS Level 3 Physical Area: Experts suggest the work section of high-rise building is divided by physical area or location vertically to indicate storeys and also horizontally to indicate tower zone.

- WBS Level 4 Sub-Work Section: It is the further decomposition of architectural work, it is: Wall, Floor, Ceiling, Door \& Window, Door \& Window Hardware, Façade, Roof, Sanitair, and Others.

- WBS Level 5 Work Package: It is the lowest level of WBS components, it represents the degree to which the performance of each work package can be assigned to an individual or organization.

The complementary levels are:

- WBS Level 6 Activity: It is added to the WBS template to help the project manager identify the work to be done on the lower level of work package. Project managers can add as much of the activity as they need to understand the details of the work to be done in order to properly deliver the project.

- WBS Level 7 Resources: This level divide the resources needed to perform the activity, it is the materials, equipment, and labor.

The activity level is highly dependent on the alternative of design or method. The alternative must be set first in order to breakdown the activity up to the resources, thus it is not a hierarchy within the WBS structure, but as a determinant to detail the activity.

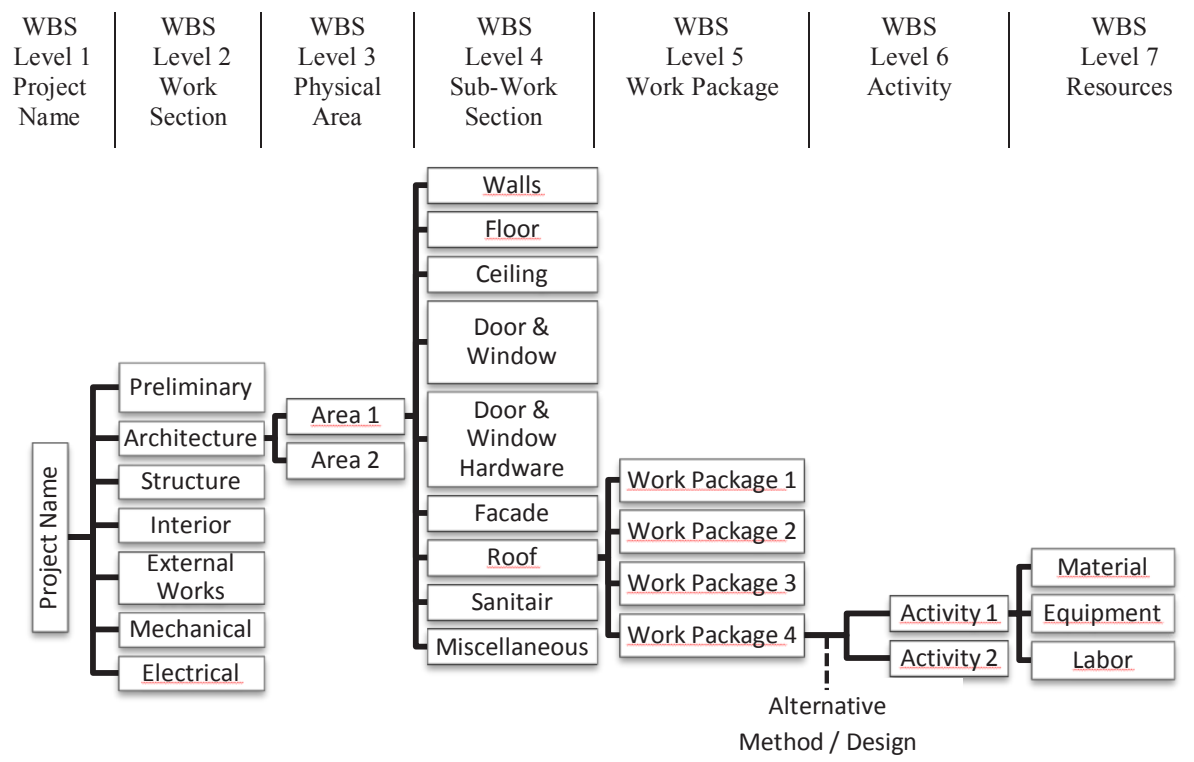

Fig. 1. Diagram tree of architectural works standardized WBS 


\subsection{Dominant risks on quality performance}

To identify the risk variable, the standardized WBS framework was used as risk category towards quality performance from the last primary level of 'Level 5: Work Package', then 'Alternative Method/Design', 'Level 6: Activity', and 'Level 7: Resources'. There are 36 risk variables that are narrowed to 14 dominant risk variables after qualitative risk analysis and the highest risk score obtained from the category of WBS Level 7 Labor Resources.

Table 1. Dominant risk variables on quality performance

\begin{tabular}{|c|c|c|c|}
\hline \multicolumn{2}{|r|}{ RISK VARIABLE } & SCORE & RANK \\
\hline \multicolumn{4}{|c|}{ RISK CATEGORY: WBS LEVEL 5 WORK PACKAGE } \\
\hline $\mathrm{X} 3$ & Subcontractor qualification is not in accordance with planning & 0.100 & 12 \\
\hline $\mathrm{X} 6$ & Subcontractor productivity is not in accordance with planning & 0.106 & 9 \\
\hline \multicolumn{4}{|c|}{ RISK CATEGORY: ALTERNATIVE METHOD/DESIGN } \\
\hline $\mathrm{X} 8$ & Applied method does not match site condition & 0.091 & 16 \\
\hline X9 & Applied method is not in accordance with planning & 0.085 & 19 \\
\hline \multicolumn{4}{|c|}{ RISK CATEGORY: WBS LEVEL 6 ACTIVITY } \\
\hline $\mathrm{X} 10$ & Installation does not conform the specification or construction drawing & 0.107 & 8 \\
\hline $\mathrm{X} 11$ & Installation is not in accordance with procedure & 0.088 & 18 \\
\hline \multicolumn{4}{|c|}{ RISK CATEGORY: WBS LEVEL 7 MATERIAL RESOURCES } \\
\hline $\mathrm{X} 14$ & Material usage exceeds planning & 0.097 & 14 \\
\hline $\mathrm{X} 15$ & Quality of applied material is not in accordance with planning & 0.104 & 10 \\
\hline \multicolumn{4}{|c|}{ RISK CATEGORY: WBS LEVEL 7 EQUIPMENT RESOURCES } \\
\hline $\mathrm{X} 20$ & Planned equipment productivity lower than actual needs & 0.080 & 24 \\
\hline $\mathrm{X} 25$ & Equipment specification is not in accordance with planning & 0.069 & 29 \\
\hline \multicolumn{4}{|c|}{ RISK CATEGORY: WBS LEVEL 7 LABOR RESOURCES } \\
\hline $\mathrm{X} 26$ & Lower labor productivity & 0.155 & 2 \\
\hline $\mathrm{X} 27$ & Unsuitable manpower planning (wrong specialization) & 0.173 & 1 \\
\hline $\mathrm{X} 31$ & Labor is not ready to implement new methods & 0.121 & 3 \\
\hline $\mathrm{X} 33$ & Labor qualification is not according to plan & 0.120 & 4 \\
\hline
\end{tabular}

\subsection{Risk-based standardized WBS}

The analysis resulting risk responses that can be distinguished into 5 different categories:

(1) Addition to related WBS: Items added to related WBS element which is exposed to risk. It can be included into the WBS element by some consideration, whether the risk response is a specific item for a particular job so it is always be done and largely affecting project costs. This decision may vary depending on the project conditions.

(2) Addition to another WBS: Items added to another sub-work package (Level 4) different than the related Architecture WBS which is exposed to risk, or additions to Preliminary, Structure, or M/E WBS (Level 2). Infrastructure facilities as operational support and managerial activity considered as overhead item can be included in Preliminary.

(3) Addition to managerial item: Items required to execute a project or a risk response related to project managerial from the initial stage to project closure.

(4) Addition to activity requirement: Items added to requirements, which can be incorporated into Work Instructions, specification, or contracts. It is also related to organizational policy, whether the risk response does not largely affecting cost so it can be included in Work Instructions, or when the work is transferred to another party then the price-forming should consider the risk response.

(5) Affecting WBS coefficient: Risk response can also affect the coefficients related with the structure of resources. The coefficient on the material relates to waste and material composition, the coefficient on the equipment relates to equipment capacity, and the coefficient on labor relates to labor productivity. In this case, if the risk response affects 
the WBS coefficients, it is important for the project executor to concern regarding the costing strategy since it is tied to the structure of unit price, so that the risk response can be considered for bidding whether it is included in unit price structure or not.

The pattern recognition analysis resulting 23 Preventive Actions and 18 Corrective Actions as risk responses. Table 2 and Table 3 shows the sample of category mapping.

Table 2. Risk response category mapping for preventive action

\begin{tabular}{|c|c|c|c|c|c|c|c|}
\hline \multirow{2}{*}{ NO } & \multirow{2}{*}{ PREVENTIVE ACTION } & \multicolumn{5}{|c|}{ CATEGORY } & \multirow{2}{*}{ RECOMMENDATION } \\
\hline & & 1 & 2 & 3 & 4 & 5 & \\
\hline P1 & $\begin{array}{l}\text { Incorporate the requirements of the } \\
\text { specialization and numbers of labor in the } \\
\text { contract }\end{array}$ & & $\bullet$ & $\bullet$ & & & $\begin{array}{l}\text { Contract / WBS Preliminary: } \\
\text { Project Document \& } \\
\text { Administration } \\
\end{array}$ \\
\hline
\end{tabular}

Table 3. Risk response category mapping for corrective action

\begin{tabular}{|c|c|c|c|c|c|c|c|}
\hline \multirow{2}{*}{ NO } & \multirow{2}{*}{ CORRECTIVE ACTION } & \multicolumn{5}{|c|}{ CATEGORY } & \multirow{2}{*}{ RECOMMENDATION } \\
\hline & & 1 & 2 & 3 & 4 & 5 & \\
\hline C1 & Perform rework on the failed part or entirely & & & $\bullet$ & & & Managerial \\
\hline
\end{tabular}

There are 14 dominant risk variables for the RBS input, and there are Wall works, Door $\&$ window works, and Floor works, as the dominant sub work section resulting from Pareto analysis for the WBS input of RBSxWBS matrix. The results are 14 risk responses, and Table 4 shows the sample from the Sub Work Section: Wall

Table 4. Risk response category mapping for architectural works (RBSxWBS Matrix)

\begin{tabular}{|c|c|c|c|c|c|c|c|c|c|}
\hline \multirow{2}{*}{ NO } & \multirow{2}{*}{ RBS } & \multirow{2}{*}{ WBS } & \multirow{2}{*}{ RISK RESPONSE } & \multicolumn{5}{|c|}{ CATEGORY } & \multirow{2}{*}{$\begin{array}{l}\text { RECOMMEN- } \\
\text { DATION }\end{array}$} \\
\hline & & & & 1 & 2 & 3 & 4 & 5 & \\
\hline \multicolumn{10}{|c|}{ Sub work section: Wall } \\
\hline 1 & $\begin{array}{l}\mathrm{X} 6 \\
\mathrm{X} 26\end{array}$ & $\begin{array}{l}\text { Work } \\
\text { Package- } \\
\text { Brick wall }\end{array}$ & $\begin{array}{l}\text { Activity: } \\
\text { Wall Crashing \& Repairing; } \\
\text { Material res.: Concrete filler, } \\
\text { Wiremesh }\end{array}$ & $\bullet$ & & & & & $\begin{array}{l}\text { Activity on } \\
\text { Brick wall work } \\
\text { package }\end{array}$ \\
\hline
\end{tabular}

Here is the sample of standardized WBS which is enhanced by the risk responses obtained for Sub work section : Wall of interior brick wall.

Table 5. Risk-based standardized WBS for interior brick wall

* $\quad$ : Risk response (development of the standardized WBS)

\begin{tabular}{|c|l|l|l|l|l|}
\hline $\begin{array}{c}\text { WBS } \\
\text { L. } 4\end{array}$ & $\begin{array}{c}\text { WBS } \\
\text { L. 5 }\end{array}$ & $\begin{array}{c}\text { Alt. } \\
\text { Method/ } \\
\text { Design }\end{array}$ & $\begin{array}{c}\text { WBS L. 6 } \\
\text { Activity }\end{array}$ & \multicolumn{1}{c|}{$\begin{array}{c}\text { WBS L. 7 } \\
\text { Resources }\end{array}$} & Requirement \\
\hline Wall & $\begin{array}{l}\text { Brick } \\
\text { Wall }\end{array}$ & $\begin{array}{l}\text { Interior } \\
\text { Brick wall }\end{array}$ & $\begin{array}{l}\text { Brick wall } \\
\text { installation }\end{array}$ & $\begin{array}{l}\text { * Practice beam \& } \\
\text { column } / 9 \mathrm{~m}^{2} ; \text { Anchor/5 } \\
\text { row installing }\end{array}$ \\
\hline & & & Bonding plastering & & \\
\hline & & & Mortar plastering & & \\
\hline & & & Cement plastering & & \\
\hline & & & *Primer coating & & \\
\hline & & & Interior painting & & \\
\hline & & & $\begin{array}{l}\text { *Wall crashing \& } \\
\text { repairing; }\end{array}$ & $\begin{array}{l}\text { *Material: Concrete } \\
\text { filler, Wiremesh }\end{array}$ & \\
\hline
\end{tabular}

\section{Conclusion}

The first research objective indicates the standardized WBS consists of 5 primary level and 2 complementary level. The second research objective generates 14 dominant risks and the 
highest risk score obtained from the category of WBS Level 7 Labor Resources. The third research objective shows that not every risk responses can be adopted directly into related WBS structure, there are 5 different categories and the application becomes project executor decision which is influenced by corporate policy or project conditions. The riskbased standardized WBS can be utilized for the basis of quality planning to help project executor identifies project works to the smallest items and setting quality objective.

The authors would like to thank the financial support provided by Universitas Indonesia through the PITTA 2017 funding scheme under Grant no. 862/UN2.R3.1/HKP.05.00/2017 managed by the Directorate for Research and Public Services (DRPM) Universitas Indonesia.

\section{References}

1. W. S. Andi, Y. Hendarlim, Faktor-Faktor Penyebab Rework pada Pekerjaan Konstruksi. Civil Engineering Dimension/CED, 7.1, 22-29 (2005)

2. F. Fakih, Banyak Rusunawa Bocor dan Retak, Ahok akan Hati-Hati Berikan Tender, Retrieved 01 November 2016 from https://www.merdeka.com/jakarta/banyakrusunawa-bocor-dan-retak-ahok-akan-hati-hati-berikan-tender.html (2016)

3. S. Ponticelli, W. O'Brien, F. Leite, 5th International/11th Construction Specialty Conference, 1-10 (2015)

4. ISO 9001 and Risk, http://isotc.iso.org/, Retrieved 01 October 2016 from http://isotc.iso.org/livelink/livelink/fetch/2000/2122/-8835176/-8835848/8835872 /8835883/ISO9001andRisk.docx (2016)

5. O. Zwikael, Critical Planning Processes in Construction Projects, Cons. Innov., 9, 372387 (2009)

6. T. Leemann, Managing the Chaos of Change, The J. of Bus. Strategy, 23.5, 11-15 (2002)

7. K. Blyth, J. Lewis, A. Kaka, Developing Framework for Standardized Work Programme for Building Project, Cons. Innov., 4, 193-210 (2004)

8. J.V. Tonder, M. Bekker, Analysis of a Methodology to Obtain a Work Breakdown Structure Built Up From Interdependent Key Project Deliverable Packages. African Rhythm Project Management Conference. Johannesburg South Africa, 1-13 (2002)

9. B. Atkin, Stereotypes and themes in building designs: insights for model builders, Cons. Mngmt. and Eco., 11, 119-30 (1993)

10. C. Gray, J. Little, The classification of work packages to determine the relationship between design and construction, Occasional paper No. 18, Department of Construction Management and Economics University of Reading (1985)

11. J.M. Nicholas, Project Management for Business and Engineering Principles and Practice (Elsevier, Oxford, 2004)

12. Y.M. Ibrahim, A. Kaka, G. Aouad, M. Kagioglou, Framework for a generic work breakdown structure for building projects, Const. Innovation, 9.4, 388-405 (2009)

13. S.T. Lai, A WBS-Based Plan Changeability Measurement Model for Reducing Software Project Change Risk, Lecture Notes on Software Engineering, 2.1, 94-99 (2014)

14. L. Su, WBS-based Risk Identification for the Whole Process of Real Estate Project and Countermeasures, National Conference on Information Technology and Computer Science (2012) 